AGRICULTURE AND BIOLOGY JOURNAL OF NORTH AMERICA

ISSN Print: 2151-7517, ISSN Online: 2151-7525, doi:10.5251/abjna.2011.2.1.47.51

(C) 2011, ScienceHu $\beta$, http://www.scihub.org/ABJNA

\title{
Performance and economic analysis of cockerel chicks fed enzyme supplemented brewer's dried grains groundnut cake-based diets
}

\author{
Isikwenu, J.O. \\ Department of Animal Science, Delta State University, Asaba Campus, Delta State, Nigeria. \\ E-mail jisikwenu@yahoo.com Phone: (234)8036786107

\begin{abstract}
The effect of replacing groundnut cake (GNC) with enzyme supplemented brewer's dried grains (BDG) at $0,25,50,75$ and $100 \%$ graded levels in cockerel chicks diets was investigated. Five dietary treatments were formulated to be isonitrogenous and isocaloric to provide $23 \%$ crude protein and $2895.77 \mathrm{Kcal} / \mathrm{kg}$ metabolizable energy. Two hundred and twenty five day old cockerel chicks (Abor-Acre breed) were randomly allocated to five treatments replicated thrice with 15 chicks per replicate, fed and watered ad libitum in deep litter pens for 4 weeks. Means of body weight, weight gain, feed intake and feed: gain ratio of cockerel chicks fed the control diet, 25 and $50 \%$ enzyme supplemented brewer's dried grains diets were significantly $(P<0.05)$ better than those fed 75 and $100 \%$ inclusion levels. Mortality was approximately $6 \%$. It was economically more profitable to use enzyme supplemented BDG in replacing GNC in cockerel chicks diets.
\end{abstract}

Keywords: Enzyme, Supplemented, Cockerel Chicks, Brewer's dried grains, Groundnut cake.

\section{INTRODUCTION}

The protein deficit of monogastric livestock feed situation is more critical than caloric inadequacies. Protein sources for poultry feed are expensive and in most cases directly required by man as food. Brewer's dried grains (BDG) is a cheaper alternative to groundnut cake (GNC), is readily available, not directly or indirectly required by man for food and can supply the same quality protein as GNC (Isikwenu, 2006). The major limitation to the use of BDG as a source of plant protein is its high fibre content (Onwukdike, 1993; Ademosun, 1973). To reduce its fibre content, Isikwenu et al. (2008) subjected BDG to urea-treatment and fermentation and successfully used it to replace up to $50 \%$ of GNC (16.70\% of the diet) in broiler starter diets. This indicate that further processing or use of additives that can break-up the non-starch polysaccharides in BDG into easily digestible smaller polymers will improve its nutritive value and utilization. The use of exogenous enzymes in monogastric diets is said to have numerous benefits including; the removal of anti-nutritional factors; increased digestibility of existing nutrients; increased digestibility of non-starch polysaccharides (NSPs) and supplementing host endogenous enzymes (Classen and Cooper, 1999). The enzymes mostly used in monogastric diets are predominantly glycanases, which cleave non-starch polysaccharides (NSPs) into smaller polymers, thereby removing their ability to form viscous digesta and enhancing nutrient digestibilities (Choct et al., 1995). Research information on the use of enzyme supplemented BDG for poultry is relatively limited. This study was conducted to investigate the effect of replacing GNC with enzyme supplemented BDG in cockerel chicks diets.

\section{MATERIALS AND METHODS}

Experimental Site: This experiment was carried out at the Poultry Research Unit of the Department of Animal Science, Delta State University, Asaba Campus. It has a mean annual rainfall, temperature and relative humidity of $1137 \mathrm{~mm}, 32.7^{\circ} \mathrm{C}$ and $82 \%$ respectively and lies on latitude $5^{0} 30^{1}$ and $45^{1} \mathrm{~N}$ of the equator and longitude $5^{0} 40^{1}$ and $6^{0} \mathrm{E}$ of the Greenwich Meridian.

Experimental Birds and Management: A total of two hundred and twenty-five (225) day old cockerel chicks (Abor-Acre breed) were used in this study. The birds were managed in a deep litter house of fifteen pens with dimensions of $2.04 \mathrm{~m} \times 2.03 \mathrm{~m}$ for the four weeks study period. Feed and water were provided ad libitum while necessary prophylaxis and vaccination were administered.

Experimental Design: The cockerel chicks were randomly allotted into five treatment groups with three replicates on equal weight basis in a completely randomized design. Each treatment group consists of 45 cockerel chicks and 15 in each replicate.

Experimental Diets: Brewer's dried grains (BDG) was used to replace groundnut cake (GNC) at $0,25,50$, 
75 and 100\% levels in cockerel chicks diets on protein equivalent basis. Five treatment diets were formulated to be isonitrogenous and isocaloric to supply $23 \%$ crude protein and $2895.77 \mathrm{kcal} / \mathrm{kg}$ metabolizable energy. The experimental diets containing 25, 50, 75 and 100\% replacement levels were fed with enzyme supplementation(Hemicell $\left.{ }^{R}\right)$ used at $0.5 \%(500 \mathrm{~g} / \mathrm{ton})$ of the feed. The composition of the cockerel chicks diets and their proximate compositions are presented in Table 1.

Table 1: Composition of Experimental Cockerel Chicks Diets (0-4 weeks)

\begin{tabular}{|c|c|c|c|c|c|}
\hline \multirow{2}{*}{$\begin{array}{l}\text { Replacement } \\
\text { Level (\%) }\end{array}$} & \multicolumn{5}{|c|}{ Dietary Treatments } \\
\hline & $\begin{array}{l}100 \text { GNC } \\
00 \text { EBDG }\end{array}$ & $\begin{array}{c}75 \text { GNC } \\
25 \text { EBDG }\end{array}$ & $\begin{array}{c}50 \text { GNC } \\
50 \text { EBDG }\end{array}$ & $\begin{array}{l}25 \text { GNC } \\
75 \text { EBDG }\end{array}$ & $\begin{array}{l}00 \mathrm{GNC} \\
100 \text { EBDG }\end{array}$ \\
\hline \multicolumn{6}{|l|}{ Ingredients } \\
\hline Maize(Yellow) & 56.20 & 54.52 & 52.60 & 50.80 & 48.90 \\
\hline Groundnut cake & 32.00 & 24.88 & 16.00 & 8.00 & - \\
\hline $\begin{array}{l}\text { Brewer's Dried Grains } \\
\text { +Enzymes }\end{array}$ & - & 8.80 & 19.60 & 29.40 & 39.30 \\
\hline Fish Meal & 5.50 & 5.50 & 5.50 & 5.50 & 5.50 \\
\hline Bone Meal & 3.50 & 3.50 & 3.50 & 3.50 & 3.50 \\
\hline Oyster Shell & 1.50 & 1.50 & 1.50 & 1.50 & 1.50 \\
\hline Premix* & 0.50 & 0.50 & 0.50 & 0.50 & 0.50 \\
\hline Salt & 0.50 & 0.50 & 0.50 & 0.50 & 0.50 \\
\hline Methionine & 0.30 & 0.30 & 0.30 & 0.03 & 0.30 \\
\hline Total & 100.00 & 100.00 & 100.00 & 100.00 & 100.00 \\
\hline \multicolumn{6}{|l|}{ Calculated Analysis: } \\
\hline Crude Protein (\%) & 23.03 & 23.05 & 23.02 & 23.02 & 23.04 \\
\hline Crude Fibre (\%) & 5.11 & 5.57 & 6.12 & 6.63 & 7.15 \\
\hline Metabolizable Energy(Kcal/kg) & 2895.77 & 2879.15 & 2860.04 & 2852.17 & 2823.39 \\
\hline \multicolumn{6}{|l|}{ Determined Analysis: } \\
\hline Dry Matter (\%) & 92.00 & 92.95 & 92.90 & 92.50 & 92.90 \\
\hline Crude Fibre (\%) & 7.00 & 8.00 & 10.00 & 12.40 & 14.10 \\
\hline Ether Extract (\%) & 6.00 & 7.50 & 8.20 & 9.60 & 9.80 \\
\hline Crude Protein (\%) & 23.12 & 23.10 & 23.08 & 22.99 & 22.98 \\
\hline Ash (\%) & 10.00 & 10.00 & 12.00 & 13.00 & 13.60 \\
\hline NFE & 45.88 & 44.35 & 39.62 & 34.51 & 32.42 \\
\hline
\end{tabular}

${ }^{*}$ Each $2.5 \mathrm{~kg}$ vitamin-mineral premix provided the following:

A 12,000,000 IU; $D_{3} 2,500,000 \mathrm{IU} ; E$ 30,000 IU; K 2,500mg; $B_{1} 2$ 2,000mg; $B_{2} 4,500 \mathrm{mg} ; B_{12}$ 40,000mg; Niacin 15,000mg; Pantothenic acid 1,500mg; Folic acid 50mg; Biotin 30,000mg; Chlorine 80,000mg; Manganese 50,000mg; Zinc 20,000mg; Iron 5,000mg; Copper 1,000mg; lodine 200mg; Selenium 500mg; Cobalt 200mg. Enzyme used is Hemicell ${ }^{R}$ at 500g/ton of feed. GNC: Groundnut Cake, EBDG: Enzyme Supplemented brewer's dried grains.

Measurements: Body weight performance, feed intake and mortality were recorded on replicate basis weekly while feed conversion ratio was obtained according to Lambert et al. (1936). Economic analysis of cockerel chicks production was based on the cost of the diets compounded from the prevailing market price of the ingredients at the time of purchase. This information was used to compute the cost of feed consumed per kg weight gain for each diet, the cost differential and relative cost benefit values of the diets in relation to the control.

Chemical Analysis: The chemical analysis of the proximate compositions of the test ingredient (Table
2) and experimental diets (Table 1) were carried out according to the procedure of A.O.A.C (1990).

Statistical Analysis: Data obtained were subjected to analysis of variance and treatment means were compared by Duncan's multiple range test (Duncan, 1955) using SPSS 10.0 package. 
Table 2: Chemical Composition of Groundnut Cake (GNC) and Brewer's Dried Grains (BDG)

\begin{tabular}{|l|c|c|}
\hline \multicolumn{1}{|c|}{$\begin{array}{c}\text { Chemical } \\
\text { Components }\end{array}$} & GNC & BDG \\
\hline Crude Protein & 45.00 & 27.90 \\
\hline Ether Extract & 9.16 & 7.40 \\
\hline Crude Fibre & 3.81 & 11.70 \\
\hline Ash & 5.51 & 4.80 \\
\hline Calcium & 0.20 & 0.30 \\
\hline Phosphorous & 0.60 & 0.88 \\
\hline TDN & 76.00 & 78.00 \\
\hline ME Kcal/kg (Swine) & 3185.00 & 2240.00 \\
\hline ME Kcal/kg (Poultry) & 2530.00 & 2513.00 \\
\hline Lysine & 1.73 & 0.90 \\
\hline Methionine & 0.44 & 0.60 \\
\hline Cystein & 0.72 & 0.40 \\
\hline Arginine & 5.00 & 1.30 \\
\hline Tryptophan & 0.49 & 0.40 \\
\hline
\end{tabular}

Source: (Aduku, 1993)

\section{RESULTS}

The results of the performance of cockerel chicks are presented in Table 3

Mean body weight, weight gain, feed intake and feed: gain ratio of cockerel chicks fed the control diet and up to $50 \%$ replacement levels of enzyme supplemented brewer's dried grain (BDG) were significantly $(P<0.05)$ better than those fed 75 and $100 \%$ replacement levels of enzyme supplemented BDG diets. The results of the cost- benefit analysis of the production of cockerel chicks fed, the experimental diets are presented in Table 4. There was significant $(P<0.05)$ reduction in the amount of total feed consumed per bird, cost of total feed consumed per bird and the cost per $\mathrm{kg}$ feed with increased levels of enzyme supplemented BDG in the diets of cockerel chicks. Total feed consumed by cockerel chicks fed the control diet were similar ( $P$ > $0.05)$ to those fed $25 \%$ and $50 \%$ enzyme supplemented BDG diets but significantly $(P<0.05)$ higher than those of 75 and $100 \%$ replacement levels. The cost of producing one kilogram of live weight of a cockerel chick during this stage reduced though not significant $(P>0.05)$ as the level of enzyme supplemented BDG increased in the diets. The cost differential and relative cost-benefit per kilogram gain generally $(P<0.05)$ increased with increasing level of enzyme supplemented BDG in the diets. High mortality of $6 \%$ was caused by frequent attacks on chicks by wild cats.

Table 3: Performance Characteristics of Cockerel Chicks Fed Experimental Diets (0-4 weeks).

\begin{tabular}{|c|c|c|c|c|c|c|}
\hline $\begin{array}{c}\text { Replacement } \\
\text { Levels (\%) }\end{array}$ & $\begin{array}{c}100 \text { GNC } 00 \\
\text { EBDG }\end{array}$ & $\begin{array}{c}75 \text { GNC } \\
25 \text { EBDG }\end{array}$ & $\begin{array}{c}50 \text { GNC } \\
50 \text { EBDG }\end{array}$ & $\begin{array}{c}25 \text { GNC } 75 \\
\text { EBDG }\end{array}$ & $\begin{array}{c}00 \text { GNC } \\
100 \text { EBDG }\end{array}$ & SEM \\
\hline Body Weight (g/bird) & $384.36^{\mathrm{a}}$ & $352.95^{\mathrm{a}}$ & $345.52^{a}$ & $256.69^{b}$ & $273.53^{b}$ & 15.84 \\
\hline Feed Intake $(\mathrm{g} / \mathrm{b} / \mathrm{d})$ & $40.10^{a}$ & $37.22^{\mathrm{a}}$ & $36.27^{a}$ & $28.94^{b}$ & $29.45^{b}$ & 1.45 \\
\hline
\end{tabular}

$a, b$ means with different superscripts in the same row are significantly $(p<0.05)$ different.

(g/b/d): grams per bird per day. GNC: Groundnut Cake, EBDG: Enzyme Supplemented brewer's dried grains.

Table 4: Economic Analysis of Cockerel Chicks Fed Experimental Diets (0-4 weeks)

\begin{tabular}{|c|c|c|c|c|c|c|}
\hline Parameters & $\begin{array}{c}100 \text { GNC } 00 \\
\text { EBDG }\end{array}$ & $\begin{array}{c}75 \text { GNC } \\
25 \text { EBDG }\end{array}$ & $\begin{array}{c}50 \text { GNC } 50 \\
\text { EBDG }\end{array}$ & $\begin{array}{c}25 \text { GNC } 75 \\
\text { EBDG }\end{array}$ & $\begin{array}{c}00 \text { GNC } \\
100 \text { EBDG }\end{array}$ & SEM \\
\hline $\begin{array}{l}\text { Total feed } \\
\text { consumed(kg/bird) }\end{array}$ & $1.04^{\mathrm{a}}$ & $0.97^{\mathrm{ab}}$ & $0.96^{\text {ab }}$ & $0.78^{\mathrm{bc}}$ & $0.76^{\mathrm{C}}$ & 0.04 \\
\hline Cost/kg feed & $88.39^{a}$ & $83.10^{a}$ & $71.41^{b}$ & $71.51^{b}$ & $67.80^{b}$ & 2.32 \\
\hline $\begin{array}{l}\text { Cost of Total feed } \\
\text { Consumed/bird }\end{array}$ & $92.28^{a}$ & $76.45^{\mathrm{ab}}$ & $68.62^{\mathrm{bc}}$ & $55.78^{\mathrm{C}}$ & $51.74^{\mathrm{C}}$ & 4.41 \\
\hline Cost/kg Weight & $233.18^{a}$ & $221.27^{\mathrm{a}}$ & $198.02^{a}$ & $209.53^{\mathrm{a}}$ & $215.70^{\mathrm{a}}$ & 5.75 \\
\hline $\begin{array}{l}\text { Cost Differential/kg } \\
\text { gain }(\AA)\end{array}$ & - & $11.91^{\mathrm{b}}$ & $35.16^{a}$ & $23.65^{a}$ & $17.49^{b}$ & 9.28 \\
\hline $\begin{array}{l}\text { Relative Cost Benefit } \\
/ \mathrm{kg} \text { gain }\end{array}$ & $100^{\mathrm{e}}$ & $105.38^{\mathrm{d}}$ & $117.73^{\mathrm{a}}$ & $111.29^{b}$ & $108.10^{C}$ & 1.58 \\
\hline
\end{tabular}

$a, b, c, d$, e means with different superscripts in the same row are significantly $(p<0.05)$ different.

GNC: Groundnut Cake, EBDG: Enzyme Supplemented brewer's dried grains. 


\section{DISCUSSION}

The average body weight, daily weight gain, feed: intake and feed gain ratio of cockerel chicks fed the control, 25 and 50\% enzyme supplemented BDG diets were similar, indicating that cockerel chicks at 0-4 weeks can tolerate inclusions of enzyme supplemented BDG of up to $50 \%(16.70 \%$ of the diet) level. Cockerel chicks fed enzyme supplemented BDG at 0, 25 and $50 \%$ inclusion levels had significantly higher feed intake than those on 75 and $100 \%$ inclusion levels, which means at 0,25 and $50 \%$ inclusion levels, the diets were equally acceptable to the cockerel chicks as they ate approximately the same quantity. The decrease in feed intake at the 75 and $100 \%$ of enzyme supplement BDG diets may be attributed to bulkiness and probably poor acceptability of the feed associated with high BDG levels compared to groundnut cake. The observed mean body weights and daily weight gains agree with the feed intake pattern of cockerel chicks, which means the inclusion levels of 25 and $50 \%$ enzyme supplemented BDG diets were able to provide adequate nutrients for tissue synthesis to achieve a growth rate comparable to the control diet that do not have any BDG. This may have been made possible by cellulases and glycanases contained in the enzyme which might have caused a cleavage of the non-starch polysaccharides (NSPs) in BDG into smaller polymers, thereby removing their ability to form viscous digesta and enhancing nutrient digestibilities (Choct et al., 1995). The 50\% replacement level which has $16.70 \%$ of the diet as enzyme supplemented BDG is an improvement on the $10 \%$ level of dietary BDG inclusion achieved in broiler chicks by Ademosun (1973) and Lopez and Carmona (1981). The improvement in body weight performance in this study are consistent with those obtained by Abubakar et al (2004) when rice bran and wheat offal diets of pullets and broiler starter chicks where supplemented with enzymes. Similar results were also reported by Isikwenu et al. (2008) when urea-treated and fermented BDG replaced groundnut cake in broiler starter diets. Enzyme treatment is capable of solubilizing high amounts of cell wall, thereby producing a good quality high level soluble carbohydrate from non-starch polysaccharides (IFRU, 2003). The higher inclusion level obtained in this study can be attributed to the enzyme supplementation effect on BDG, which results in fibre breakdown, reduction in fibre content and anti-nutritional activities, causing a release of locked-up nutrients that encouraged good performance of cockerel chicks. The lower weight gain of cockerel chicks fed 75 and 100\% inclusion levels of enzyme supplemented BDG diets might have been caused by nutrient intake restriction precipitated by lower feed intake or nutrient dilution effect of crude fibre and bulkiness of feeds. This result is supported by previous reports on the implication of restricted feed intake on growth rate and body weight performance (Fattori et al. 1991; Ubosi, 1998 and Mench, 2002). This could also result from the inability of the enzyme concentration present in the feed to cope with the amount of crude fibre (NSPs) to be degraded in the feed. The feed: gain ratio of cockerel chicks followed the same pattern with the feed intake and daily weight development, and showed that the replacement of up to $50 \%$ GNC with enzyme supplemented BDG had no negative effects on performance. There was gain in financial margin in the production cost with the inclusion of enzyme supplemented BDG as part replacement for GNC in cockerel chicks diets. It was found to be more profitable to produce cockerel chicks at 0-4 weeks with $50 \%$ enzyme supplemented BDG than GNC, even when lower weight gain was observed as enzyme supplemented BDG levels increased in the diets. This is due to the fact that enzyme supplemented BDG is much cheaper than GNC. The highest significant savings (A35.16) per kilogramme weight gain of cost differential was obtained from treatment with 50\% enzyme supplemented BDG diet.

\section{CONCLUSION}

Enzyme supplemented BDG can replace up to 50\% GNC (16.70\% of the diet) as a plant protein source in cockerel chicks diets. Based on the cost of production per kilogramme weight gain, the use of enzyme supplemented BDG is more profitable than GNC in cockerel chicks as long as inclusion level do not exceed $50 \%$.

\section{REFERENCES}

Abubakar, A; Bashar, Y.A; Abdullahi, H. and Abdullahi, A.U. (2007). Effects of supplemental avizyme on the performance of broiler starters fed graded level of wheat offal. pp 10-14. Fanimo, A.O; Idowu, O.M.O; Peters, S.O; Sogunle, A.M. and Jegede, A.V. (Eds.). In consolidating the poultry industry in West Africa. Proceedings $2^{\text {nd }}$ Nigeria International Poultry Summit. Abeokuta, Ogun State, Nigeria.

Ademosun, A.A.(1973).Evaluation of Brewer's dried grains in diets of growing chickens. British Poultry Science, 14:463-468. 
AOAC (1990). Official Methods of Analysis Association of Official Analytical Chemists $15^{\text {th }}$ edition, Washington D.C.

Choct, M., Hughes, R.J., Trimble, R.P., Angkanaporn, K., Annison, G. (1995). Non-starch polysaccharidedegrading enzymes increase the performance of broiler chicken fed wheat of low apparent metabolizable energy. Journal of Nutrition. 125:485492.

Classen, H.L. and Cooper, R. (1999). Improving animal feeding through enzyme use. Feed Notes. Volume I Issue 3.

Duncan, D.B. (1955). Multiple range and multiple F-tests. Biometrics 11:1-42.

Fattori, T.R., Wilson, H.R., Harms, R.H. and Miles, R.D. (1991). Response of broiler breeder females to feed restriction below recommended levels. 1. Growth and reproductive performance Poultry Science, 70:20-36.

International Feed Resources Unit (IFRU, 2003). Evaluation of nutritive value of roughages: Feed Upgrading by use of enzymes. The Macaulay Land Use Research Institute, Aberdeen, UK pp 1-3.

Isikwenu, J.O. (2006). The used of urea-treated and fermented brewer's dried grains in poultry diets. PhD Thesis, Department of Animal Science, Delta State University, Asaba Campus, Nigeria. pp 4-6.
Isikwenu, J.O., Omeje, S.I; Okagbare, G. and Akpodiete, O.J. (2008). Effect of replacing groundnut cake with urea fermented brewer's dried grains in broiler chicks diets. Animal Research International, 5(1):795-800.

Lambert, W.V., Ellis, N.R., Block, W. H and Titus, H. W. (1936). The role of nutrition in genetic research. The American Society of Animal Production 29:236 http://jas.fass.org/cgi/reprint/1936b/1/236-a

Lopez, J.D. and Carmona, J.F. (1981). Evaluation of Brewer's dried grains in diets of broiler chickens. Animal Feed Science Technology, 6:179-188.

Mench, J.A. (2002). Broiler Feeders: Feed restriction and welfare. World's Poultry Science Journal, 58:23-29.

Onwudike, O.C. (1993). Energy and protein requirements of broiler chicks in the humid tropics. Tropical Animal Production Investigation. 8:39-24.

SPSS 10.0. Statistical Package for the Social Sciences.SPSS/Inc Chicago, IL, 60606.

Ubosi, C.O. (1998). Effects of quantitative feed restriction on productive performance and blood constituents of broiler pullets. Pp 104-106. In: Ologhobo, A.D. and Iyayi, E.A. (Eds.). The Nigerian Livestock Industry in the $21^{\text {st }}$ Century. Proceedings of $3^{\text {rd }}$ Annual Conference of Animal Science Association of Nigeria. September $22^{\text {nd }}-24^{\text {th }} \quad 1998$, Ikeja, Lagos. 